\title{
41. 21. yüzyıl becerileri bağlamında öğrenci, öğretmen ve eğitim ortamları
}

Serkan ÇíFTCí1

\author{
Abdulkadir SAĞLAM²
}

Ahmet YAYLA3

APA: Çiftçi, S.; Sağlam, A.; Yayla, A. (2021). 21. yüzyll becerileri bağlamında öğrenci, öğretmen ve eğitim ortamları. RumeliDE Dil ve Edebiyat Araştırmaları Dergisi, (24), 718-734. DOI: 10.29000/rumelide.995863.

\section{$\ddot{0} \mathbf{z}$}

20. yüzyılda başlayan ve son yüzyılda devam eden yenilikler yaşamın her alanına etki etmektedir. Dünyadaki değişim ve yeniliklere uyum sağlayabilmek, yön verebilmek için bireylerin hayatlarının her aşamasında öğrenmeyi sürdürmeleri gerekmektedir. Dünyadaki bu hızlı değişim ve gelişim, her gün beraberinde yeni bilgiler, yeni teknolojiler ve yeni yaklaşım tarzları ortaya çıkarmaktadır. Yaşam boyu öğrenmenin sürdürülebilir hale gelmesi için en önemli etmen, eğitim sisteminin 21.yüzyıl becerilerine sahip bireyler yetiştiren bir metodu hayata geçirmesi olacaktır. Burada eğitim sisteminden, sistemi meydana getiren temel öğelerden öğrenciler, öğretmenler ve eğitim ortamının oluşturduğu yapı kastedilmektedir. Eğitim sistemlerinde öğrencilerin ihtiyaç duyacağı eğitsel donanımlar, eğitim sisteminin amaçlarına ulaşması için gereklidir. Bu amaçlar doğrultusunda 21. yy. becerilerine sahip öğrencilerin ve eğitim sisteminin çıtılarının gerekli özelliklerle donatılmış olarak işgücü piyasasına veya yüksek öğretime dâhil olması beklenir. Eğitimciler ve işgücü piyasası uzmanları, çocukların 21. yy. becerilerini kazanmaları gerektiğini vurgulamakta ve bu beceriler olmadan onların küresel eğitim ve işgücü piyasasına katılmada başarısız olabileceklerini ifade etmektedirler. Bu çalışmada 21.yüzyll becerilerinin eğitim sistemindeki yerinin incelenmesi amaçlanmıştır. Bunu yaparken 21. yüzyıl becerilerinin ve alt boyutlarının neler olduğu, bu beceriler kapsamında öğrencilerin, öğretmenlerin ve eğitim ortamlarının sahip olması gereken özelliklerin neler olması gerektiği üzerinde durulmuştur.

Anahtar kelimeler: 21.yy. becerileri, öğrenci, öğretmen, eğitim ortamı

\section{Student, teacher and educational environments in the context of 21. century skills}

\begin{abstract}
Innovations that began in the 20. century and continued in the last century affect all areas of life. In order to adapt to these changes in the world and to guide change, individuals must continue to learn at every stage of their lives. This rapid change and development in the world creates contemporary new knowledge, new technologies and new approaches. The most important factor in making lifelong
\end{abstract}

Dr., Van Yüzüncü Yıl Üniversitesi, Eğitim Bilimleri Enstitüsü, Eğitim Bilimleri ABD (Van, Türkiye), serkanciftci65@gmail.com, ORCID ID: 0000-0003-0949-1267 [Araştırma makalesi, Makale kayıt tarihi: 03.05.2021kabul tarihi: 20.09.2021; DOI: 10.29000/rumelide.995863]

$2 \quad$ Doktora, Hacettepe Üniversitesi, Eğitim Bilimleri Enstitüsü (Ankara, Türkiye), saglam6888@gmail.com, ORCID ID: 0000-0003-3023-5751

,3 Doç. Dr., Van Yüzüncü Yıl Üniversitesi, Eğitim Fakültesi, Eğitim Bilimleri Bölümü, Eğitimin Felsefesi Sosyal ve Tarihi Temelleri ABD (Van, Türkiye), ahmetyayla@yyu.edu.tr, ORCID ID: 000o-0002-5021-6649

Adres | Address

RumeliDE Dil ve Edebiyat Araştırmaları Dergisi Osmanağa Mahallesi, Mürver Ciceği Sokak, No:14/8 Kadıköy - İSTANBUL / TÜRKIYE 34714 e-posta: editor@rumelide.com

RumeliDE Journal of Language and Literature Studies

Osmanağa Mahallesi, Mürver Çiçeği Sokak, No:14/8

Kadıköy - ISTANBUL / TURKEY 34714

tel: $+905057958124,+902167730616$

e-mail: editor@rumelide.com

phone: +90 5057958124 , +90 2167730616 
learning sustainable will be the implementation of a method creted by the education system that trains and provides individuals with 21st century skills. Education system is defined as: it is a whole formed by students, teachers and the environment of education. Educational equipments that students will need in educational systems are necessary to achieve the goals of the entire educational system. For these purposes, students with 21. century skills are expected to be involved in the labour market or higher education, equipped with the necessary skills as an output of the education system. Educators and labor market experts emphasize that children must acquire 21. century skills and note that without these skills, will fail to participate in the global education and labor market. In this study, it is aimed to examine the situation of 21st century skills in the education system. While doing so, it is expalined what are the skills of the 21. century, the dimensions of 21. century skills, student characteristics, teacher characteristics, and educational environment characteristics.

Keywords: 21. century skills, student, teacher, environment of education

\section{Giriş}

Günümüzde savaşların ekonomik ve siber ortamlarda yaşandığı, ülke büyüklüklerinin toprak ya da nüfus ile değil ekonomi ile ölçüldüğü, zenginliklerin ise maden rezervleri ile değil ülkelerin start-up ve patent sayıları ile ölçüldüğü bir çağ yaşanmaktadır (Davenport, 2018). Bu çağ aynı zamanda tarihin en büyük ama en kansız savaşlarının yani ekonomik savaşların yaşandığı bir dönem olarak karşımıza çıkmaktadır (Özkan, Al ve Yavuz, 2018). Nitekim, 2020 yllının başından itibaren dünyayı etkisi altına alan Covid-19 salgını sürecinde tüm ulusların salgına karşı ilaç bulmaya yönelik çabaları insani bir mücadele olmakla birlikte esasen ekonomik bir pastadan pay kapma savaşına dönüşmüştür (Lee, 2020). Buna göre ulusların bu acımazsız rekabetçi ortamda ayakta kalabilmeleri ve mücadele edebilmelerinin ancak eğitim sistemlerini çağa uygun olarak dizayn etmeleri ile mümkün olabileceği söylenebilir.

21. yüzyılda değiş̧en dünya koşullarına uyum sağlayabilmek ve hatta değişime yön verebilmek için; yaşadığı çağı iyi anlayabilen, toplumun ihtiyaçlarını iyi analiz edebilen, yenilikçi düşünebilen, bilgiye kolay ve hızlı ulaşabilen ve en önemlisi hayat boyu öğrenmeyi yaşam tarzı haline getirebilmiş, çağın ihtiyaçlarına cevap verebilecek niteliklere sahip bireyler yetiştirmek gerekmektedir. Bu da şüphesiz eğitim sisteminin 21.yüzyıl becerilerini kazandırmaya uygun hâle getirilmesiyle olur (Uçak ve Erdem, 2020). Burada öğrencilerin, öğretmenlerin ve eğitim ortamının bu yeni duruma uygun hâle getirilmesi önemlidir. Çünkü 21.yüzyıl becerilerine sahip olmayan ve kendisini yenilemeyen bir öğretmenin kendisinden farklı öğrenciler yetiştirmesi mümkün değildir. Aynı şekilde uygun fiziki ve sosyal ortamdan yoksun verilen eğitimin etkisinin kalıcı olmayacağı açıktır. Hasırcı'ya (2018) göre eğitim ortamları, öğrenenlerin eğitsel iletişimde bulundukları ve bu ortamdaki etkinlikler ile etkileşim içerisinde olarak farklı deneyimler kazandıkları yerlerdir. Öte yandan eğitim sürecinde öğretmen kadar öğrenme ortamları da önemlidir. Eğitim paydaşlarının sürekli iletişim halinde olduğu, işbirliği ve geri dönütlerin yaygın olduğu bir eğitim ortamında öğrenenlerin gerekli kalitedeki eğitim düzeyine ulaşmaları kaçınılmazdır (Çavdar ve Doymuş, 2016). Toplumda yer edinebilmek ve söz sahibi olabilmek adına, 21. yy. becerilerine sahip ve bunları bir üst kimlik olarak kullanan bireyler doğru karar alan mekanizmalar olarak karşımıza çıkmaktadır (Boyacı ve Özer, 2019).

Çağımızda bireylerden hızlı değişim ve gelişmelere uyum sağlayabilmeleri, ulaşılan bilgiyi yaşamlarında kullanabilmeleri ve buna bağlı olarak toplumda yer edinebilmeleri, doğru kararlar alabilmeleri, üretken olabilmeleri ve yaşamlarını sürebilmeleri için 21. yüzyıl becerilerine sahip olmaları beklenmektedir.

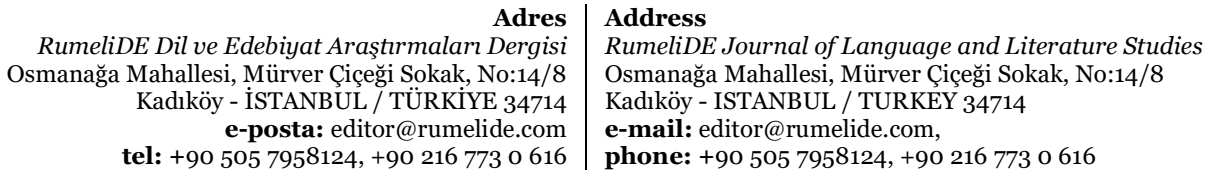

tel: $+905057958124,+902167730616$

e-mail: editor@rumelide.com,

phone: +90 505 7958124, +90 2167730616 


\section{Araştırmanın amacı ve önemi}

Bu çalışma, 21. yüzyıl becerilerinin eğitim sistemindeki yeri ve önemini ele almayı amaçlamaktadır. Bunu yaparken 21. yüzyıl becerilerinin neler olduğu, bu becerilerin boyutları, becerilerin kazandırılması amaçlanan öğrenci özellikleri, bu becerilerin kazandırılmasında verdiği eğitim ve rol model olması yönüyle birinci derecede aktif rol oynayan öğretmenlerin belirli niteliklere sahip olması gerektiği ifade edilmeye çalışılmaktadır. Ayrıca bahsedilen bu becerilerin kazandırılması sürecinde en yüksek fayda elde edilebilmesi ve karşılıklı bilgi akışlarının yaşandığı bu süreçte hem öğretmen hem de öğrenci açısından algı düzeyinin en üst seviyede açı tutulabilmesi adına süreçten maksimum verim alınmasını sağlayacak eğitim ortamının nasıl olması gerektiği açıllanmaktadır.

\section{Yöntem}

Çalışma, nitel araştırma yöntemlerinden literatür tarama ve döküman incelemesi oluşturulmuştur. Yıldırım ve Şimşek'e (2008) göre, literatürün taranması, araştırılması istenilen konulara dair bilgileri içeren yazılı materyallerin analizlerini kapsamaktadır. Nitel araştırmalarda literatürün incelenmesi doğrudan gözlem ve görüşmenin pek mümkün olmadığı durumlarda veya çalışmanın geçerliliğini artırmak adına kullanılan bir yöntemdir. Doküman analiz tekniği, yazılı ve elektronik belgelerin sistematik şekilde değerlendirilip incelenmesidir. Nitel araştırma tekniklerinden dökümantasyon tekniği, gerekli bilgilerin anlam, kavram ve yeterlilik açısından incelenmesini gerektirir (Bowen, 2009).

\section{Veri toplama araçları ve verilerin analizi}

Araştırmanın amaçları doğrultusunda 21. yüzyıl becerileriyle ilgili bilimsel çalışmalar; lisansüstü tez çalışmaları, makaleler, ilgili resmi internet siteleri ve kongrelerde sunulan sözlü ya da poster bildirileri gibi akademik yayınlar taranarak "21 .yüzyıl becerileri, eğitim ortamları" vb. anahtar kelimeleri yazılarak veriler elde edilmiştir ve analizleri yapılmıştır.

\section{Bulgular ve yorum}

Bu bölümde 21. yüzyll becerileri ile ilgili elde edilen veriler doğrultusundaki bulgulara yer verilmiştir.

\section{Yüzyıl becerileri}

İçinde bulunduğumuz çağda teknolojinin büyük bir hızla gelişimi, insan topluluklarının gereksinimlerini, hayata bakış açılarını ve olaylar karşısındaki tutumlarını, yaşam planlarını ve karşılarına çlkan problemleri ele alış biçimlerini derinden etkilemektedir. Günümüz toplumundaki bireylerin gereksinim duyduğu ussal donanım ve beceriler bireyin sosyal yaşama adapte olabilmesi ve kendi iç dünyasındaki beklentilere cevap verebilmesi bakımından önemlidir. Bu bilgi ve beceriler aynı zamanda bireyin kendine özgü bir yaşam tarzı oluşturması kısaca kendisi olabilmesine de dayanak olmaktadır. Anagün, Atalay, Kılıç, ve Yaşar'ın (2016) da belirttiği üzere, kişilerin ortaya çıkan değişmelere tepki göstermesi, teknolojiye sahip olabilmeleri, hızlı bir biçimde üretilen veri yığılmaları içinde bilgiyi tercih ederek, değerlendirerek ve analiz ederek elde etmesi ile gerçekleşir. Bireylerin elde ettikleri verileri günlük hayatlarında kullanmaları ve ürünlere çevirebilmeleri adına ana yeteneklerinin yanı sıra üst seviye yeterlilik ve becerilere de sahip olmaları gerekir.

Çağımız insanlarının iş, yurttaşlık ve kendini gerçekleştirmek için ihtiyaç duydukları beceriler geçen yüzyıldakinden çok farklıdır. 19 ve 20. yüzyllarda o dönemin becerileri olarak; ticari faaliyet

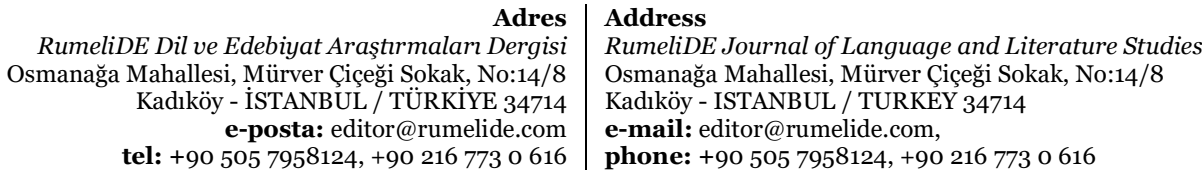


yürütebilmek, kurallar koymak veya bu kurallar çerçevesinde hareket etmek, toplumsal hayatta yüksek iletişim becerisine sahip olmak ve olabildiğince hızlı karar alabilmek gibi beceriler gösterilebilirdi (Harari, 2018). Ancak, iş hayatı ve günlük hayat arasında profesyonel davranarak bir sınır koyabilmek ve hayatın her alanında dürüst ve adil olabilmek yeterliyken bunların yeni yüzyılda ihtiyacı karşılamakta zayıf kaldığı birçok uzman tarafından (Yalçın, 2018; Göksün ve Kurt, 2017; Eryılmaz ve Uluyol, 2015; Lai ve Viering, 2012) ifade edilmiştir.

Eğitim sistemimizde ve dijital çağ olarak adlandırılan günümüz dünyasında, toplumun sosyal ve iş hayatına katılan her yeni bireyinden beklentilerine paralel olan nitelikler günden güne değişmektedir. Bugün öğrencileri iş dünyasına hazırlamak, ihtiyaç duyulan beceri ve yeterlilikler iş ve eğitim dünyasının merkezini oluşturmaktadır. Günümüzde sadece bilgiyi öğrenmek yeterli olmamaktadır. Artık kazanılan bilginin işlevselliği önemsenmektedir (Türk, 1999). 21. yüzyl becerileri, bilgi ve beceriye ek olarak performansı ve algılamayı da içermektedir. Diğer bir ifadeyle beceri ile bilginin karıştırıldığı bir olgudur (Dede, 2010: 4). Dolayısıyla bilginin mahiyetinden çok bunu öğrenme yöntemleri, kişinin kendini gerçekleştirme sürecine kattı̆̆ artı değer ve bu bilginin sosyal hayata dokunuş şekli, pratik hayatta hangi sorunsalı ortadan kaldırmaya hizmet ettiği ya da hangi yeni adıma zemin oluşturduğu gibi etmenler ön plana çıkmaktadır. Bu nedenle, eğitim sistemi açısından konuya yaklaştığımızda, çağımızda artık sadece bilgiyi öğrenciye aktarmanın yeterli olmadığı bireylere yaratıcılık, yenilikçilik, giriş̧imcilik, liderlik gibi becerileri kazandırılması gerektiği görülmektedir. Ancak bu becerilerin kazandırılmasıyla toplumlar ihtiyaç duydukları insan kaynağına erişebileceklerdir.

Bireylerin eğitim hayatlarında ve profesyonel yaşamlarında başarılı olmalarını amaçlayan pek çok devlet, eğitimciler, sivil toplum örgütü, üniversite, teşkilat, kanaat önderi gibi bileşenlerin destekleriyle farklı “21.Yüzyıl Becerileri Çerçeveleri” oluşturmuştur.

\section{P21 çerçevesi}

P21, 21.Yüzyıl Öğrenme Çerçevesi (Framework for 21st Century Learning), eğitimciler, eğitim uzmanları ve iş dünyası temsilcilerinden gelen geri bildirim dikkate alınarak, eğitim sistemlerinin nihai çıtısı olan öğrencilerin eğitim, sosyal hayat, iş hayatı ve yurttaşlık alanlarında yetkin birer birey olmalarını sağlamak için gereksinim duydukları bilgiyi, becerileri, uzmanlığı ve destek sistemlerini tanımlamak adına, eğitim uzmanları ile iş hayatı temsilcilerince verilen geri bildirimler neticesinde P21 tarafından ortaya konmuştur. P21, 21.Yüzyıl Öğrenme Çerçevesinde, aşağıdaki şekilde yer aldığı gibi, dairesel şeklin üst kısmı "öğrenme çıktılarını”, alt kısmıysa "destek sistemlerini” göstermektedir. 21. Yüzyıl öğrenme çerçevesi bağlamında amaç, yalnızca 21.yüzyıl becerilerinin ortaya konulması değil, ayrıca belirlenen bu becerilerin diğer eğitim sistemlerini de bütünleştirecek şekilde, eğitimin ana noktalarının her kademesine entegre edilmesidir. Ayrıca bunun da daimi bir şekilde geliştirilmesi gerektiği açıkça ifade edilmiştir (Bialik ve Fadel, 2015).

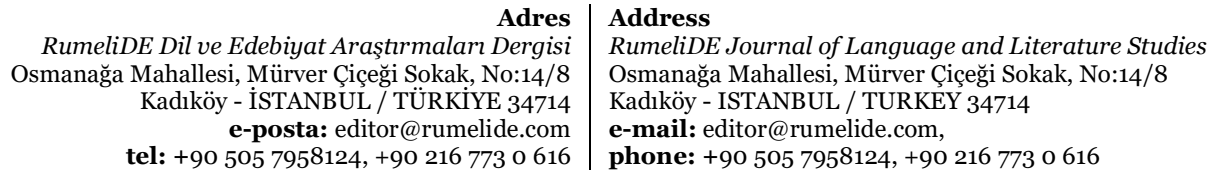

tel: $+905057958124,+902167730616$ 


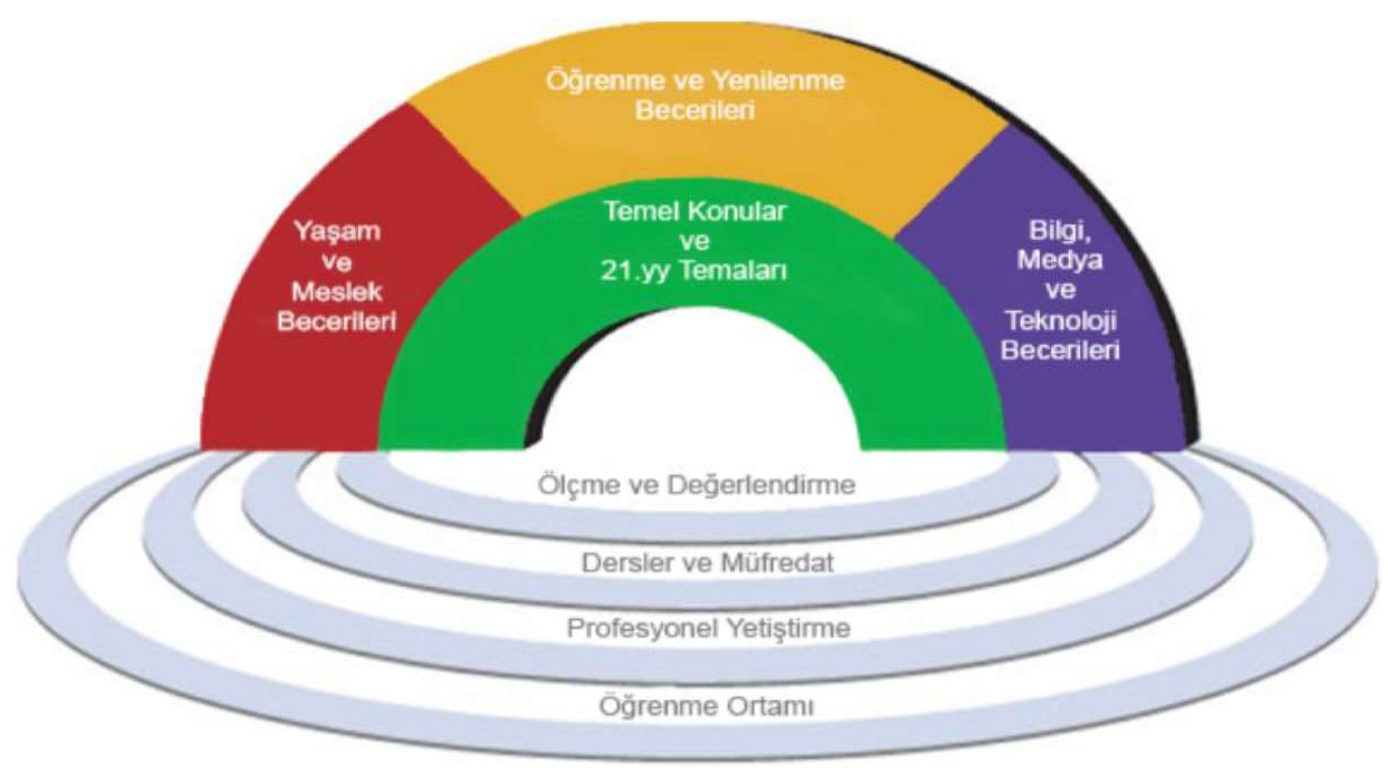

Şekil 1. P21 21. Yüzyll Öğrenme Çerçevesi (Battelle for Kids, 2021)

Şekil 1'e bakıldığında modelin merkezinde Temel Konular ve 21.yüzyıl temalarının bulunduğu görülmektedir. Temel konular matematik, dünya dilleri, dil sanatları, ekonomi, İngilizce, bilim, okuma, tarih, sanat, coğrafya, devlet ve vatandaşlık şeklinde ifade edilmiştir (P21, 2021). "Öğrenme ve Yenilik Becerileri” başlığı altında yaratıcı düşünme, iletişim ve iş birliği, problem çözme ve eleştirel düşünme becerilerini; "Bilgi, Medya ve Teknoloji Becerileri” başlığı altında bilgi okuryazarlığını, medya okuryazarlığını ve bilgi-iletişim teknolojileri okuryazarlığını; son olarak "Yaşam ve Kariyer Becerileri" başlı̆̆ altında esneklik ve uyum, sosyal beceriler, üretkenlik ile hesap verebilirlik, kendini yönetme ve liderlik becerilerini saymak mümkündür (Trilling ve Fadel, 2009). Temel konularla bütünleştirilmesi tavsiye edilen 21.yüzyll becerileri ise yaşam ve meslek becerileri, bilgi, medya ve teknoloji becerileri ile öğrenme ve yenilenme becerileridir.

21.yüzyıl becerileri hakkında çeşitli sınıflamalar yapılmıştır. Bu sınıflamaların bazıları Tablo 1'de verilmiştir.

\begin{tabular}{|c|c|c|}
\hline Sinıflamayı yapan & Boyut & Açıklama \\
\hline \multirow{3}{*}{ P21 Çerçevesi } & $\begin{array}{l}\text { Öğrenme ve } \\
\text { Yenilenme }\end{array}$ & $\begin{array}{l}\text { Eleştirel düşünme, yenilik, iletişim, problem çözme, } \\
\text { yaratıcılık ve iş birliğidir. }\end{array}$ \\
\hline & $\begin{array}{l}\text { Bilgi, Medya ve } \\
\text { Teknoloji } \\
\text { Becerileri }\end{array}$ & Bilgi, medya ve teknoloji okuryazarlığıdır. \\
\hline & $\begin{array}{l}\text { Yaşam ve Kariyer } \\
\text { Becerileri }\end{array}$ & $\begin{array}{l}\text { Liderlik, kendini yönetme, girişkenlik, üretkenlik ve } \\
\text { sosyal-kültürlerarası becerilerdir. }\end{array}$ \\
\hline \multirow{3}{*}{$\begin{array}{l}\text { The American National Research } \\
\text { Council [NRC] (Amerikan Ulusal } \\
\text { Araştırma Konseyi) }\end{array}$} & Bilişsel Beceriler & $\begin{array}{l}\text { Eleştirel düşünme, sistematik düşünme ve sıra dışı } \\
\text { problemleri çözmedir. }\end{array}$ \\
\hline & $\begin{array}{l}\text { Kişilerarası } \\
\text { Beceriler }\end{array}$ & $\begin{array}{l}\text { Grupla çalışma, karmaşık iletişim, çeşitliliklere } \\
\text { saygı, kültürel duyarlılık ve sosyal becerilerdir. }\end{array}$ \\
\hline & $\begin{array}{l}\text { İçsel-Özsel } \\
\text { Beceriler }\end{array}$ & $\begin{array}{l}\text { Öz-yönetim, kişisel gelişim, zaman yönetimi, } \\
\text { özdüzenleme becerilerinden meydana gelmektedir. }\end{array}$ \\
\hline \multicolumn{2}{|c|}{$\begin{array}{r}\text { Adres } \\
\text { RumeliDE Dil ve Edebiyat Araştrmalart Dergisi } \\
\text { Osmanağa Mahallesi, Mürver Cicceği Sokak, No:14/8 } \\
\text { Kadıköy - İTANBUL / TÜRKIYY } 34714 \\
\text { e-posta: editor@rumelide.com } \\
\text { tel: +990 505 7958124, +90 216 773 o 616 }\end{array}$} & $\begin{array}{l}\text { Address } \\
\text { RumeliDE Journal of Language and Literature Studies } \\
\text { Osmanağa Mahallesi, Mürver Ciceeği Sokak, No:14/8 } \\
\text { Kadıköy - ISTANBUL / TURKEY } 34714 \\
\text { e-mail: editor@ rumelide.com, } \\
\text { phone: +90 505 7958124, +90 } 216773 \text { o } 616\end{array}$ \\
\hline
\end{tabular}




\begin{tabular}{|c|c|c|}
\hline \multirow{7}{*}{$\begin{array}{l}\text { International Society For } \\
\text { Technology In Education-[ISTE] } \\
\text { (Uluslararası Eğitimde Teknoloji } \\
\text { Topluluğu) }\end{array}$} & $\begin{array}{l}\text { Güçlendirilmiş } \\
\text { Öğrenciler }\end{array}$ & $\begin{array}{l}\text { Kendine has öğrenme ortamları oluşturarak, } \\
\text { öğrenme hedeflerini belirleme ve onlara ulaşma, } \\
\text { ayrıca teknolojiyi de öğrenme ortamlarında } \\
\text { kullanabilme becerilerine sahip olmadır. }\end{array}$ \\
\hline & Dijital Vatandaşlık & $\begin{array}{l}\text { Yasal, güvenli ve etik bir ortamdan oluşan dijital } \\
\text { dünyada öğrenme, yaşama ve çalışma haklarını ve } \\
\text { fırsatlarını bilerek bir arada yaşamadır. }\end{array}$ \\
\hline & Bilgi Yapılandırma & $\begin{array}{l}\text { Eleștirel düşünerek ve dijital araçları kullanarak } \\
\text { bilgileri yapılandırma, anlamlı öğrenmeler } \\
\text { oluşturma ve yaratıcı eserler üretmedir. }\end{array}$ \\
\hline & Yenilikçi Tasarımcı & $\begin{array}{l}\text { Çeşitli teknolojilerden yararlanarak kullanışlı, yeni } \\
\text { ve yaratıcı tasarımlar yapıp sorunlara çözüm } \\
\text { üretenlerdir. }\end{array}$ \\
\hline & Sayısal Düşünen & $\begin{array}{l}\text { Strateji geliştirip teknolojiden yararlanarak } \\
\text { problemleri çözendir. }\end{array}$ \\
\hline & Yaratıcı İletişimci & $\begin{array}{l}\text { Yaratıcılık becerilerini ortaya koymak adına farklı } \\
\text { kaynakları, dijital ortamları kullanabilendir. }\end{array}$ \\
\hline & Küresel İşbirlikçi & Küresel ve yerel gruplarla işbirliği içinde çalışandır. \\
\hline \multirow{3}{*}{ OECD } & Bilgi & $\begin{array}{l}\text { Disiplinlerarası bilgi, bir alana özgü derinlemesine } \\
\text { bilgi, süreçsel ve epistemik bilgidir. }\end{array}$ \\
\hline & Beceri & $\begin{array}{l}\text { Duygusal, sosyal ve bilisssel olarak uygulamaya } \\
\text { dönük olan becerilerdir. }\end{array}$ \\
\hline & Tutum ve Değerler & Küresel, toplumsal, yerel ve kişisel değerlerdir. \\
\hline
\end{tabular}

Tablo 1. 21.Yüzyıl becerileri sinıflandırmaları (NRC, 2011; ISTE, 2016; OECD, 2005)

Tablo 1'de de görüldüğü üzere literatürde 21.yüzyll becerilerini sistematik hâle getirmek ve tanımlamak amacıyla birçok kurum tarafından meydana getirilmiş sınıflandırmalar bulunmaktadır. $\mathrm{Bu}$ araştırmaların çokluğu ve çeşitliliği ulusal ve uluslararası kurum ve kuruluşların 21.yüzyıl becerilerine verdiği önemin boyutunu gözler önüne sermektedir.

\section{Yüzyıl becerilerinin alt boyutları}

21. yüzyıl becerileri genel olarak ele alındığında bütün gruplandırma seçeneklerinin lisans, kariyer ve iş piyasasına yönelik olarak planlandığı fark edilmektedir. Ancak sadece eğitim boyutu ele alınarak OECD tarafindan 2005 yllında hazırlanan The Definition And Selection Of Key Competencies raporunda başka araştırmalara paralel olarak temel yetkinliklerin; duyuşsal, osyokültürel ve bilişsel alan olarak gruplandırıldığı görülmektedir (Livingston ve Bober, 2005; OECD, 2005).

\begin{tabular}{|c|c|c|c|}
\hline Alan & Alt Alan & \multicolumn{2}{|c|}{ Alt Alanların Tanımları } \\
\hline \multirow{5}{*}{ Bilişsel Alan } & Bilgi Yönetim Becerisi & \multicolumn{2}{|r|}{ Araç kullanımı, kaynakların kullanımı, sorgulama becerisi } \\
\hline & $\begin{array}{l}\text { Bilgi Yapılandırma } \\
\text { Yeteneği }\end{array}$ & \multicolumn{2}{|r|}{ Eleştirel düşünme, fikir yürütme, bilgiyi işleme becerileri } \\
\hline & Bilgi Kullanımı Yeteneği & \multicolumn{2}{|r|}{$\begin{array}{l}\text { Analitik beceriler, yargılama ve değerlendirme, çözüm } \\
\text { üretme }\end{array}$} \\
\hline & Problem Çözme Yeteneği & \multicolumn{2}{|c|}{ Üstbiliş, yaratıcı düşünme becerileri } \\
\hline & Öz Kimlik & \multicolumn{2}{|c|}{ Kendini algılama, özsaygı, benlik saygısı } \\
\hline \multicolumn{3}{|c|}{$\begin{array}{r}\text { Adres } \\
\text { RumeliDE Dil ve Edebiyat Arassttrmaları Dergisi } \\
\text { nanağa Mahallesi, Mürver Çiçeği Sokak, No:14/8 } \\
\text { Kadıköy - İSTANBUL / TÜRKIYY 34714 } \\
\text { e-posta: editor@rumelide.com } \\
\text { tel: +90 505 7958124, +90 } 2167730616\end{array}$} & $\begin{array}{l}\text { Address } \\
\text { RumeliDE Journal of Language and Literature Studies } \\
\text { Osmanağa Mahallesi, Mürver Ciceeği Sokak, No:14/8 } \\
\text { Kadıköy - ISTANBUL / TURKEY } 34714 \\
\text { e-mail: editor@ rumelide.com, } \\
\text { phone: +90 505 7958124, +90 } 216773 \text { o } 616\end{array}$ \\
\hline
\end{tabular}




\begin{tabular}{|c|c|c|}
\hline \multirow{3}{*}{ Duyuşsal Alan } & Öz Değer & Farkındalık, güvenirlik, dürüstlük \\
\hline & Kendi Kendini Yönetme & Hedef belirleme, Öz yeterlik, sorumluluk \\
\hline & Öz Sorumluluk & Sorumluluk, başarıyı isteme, girişkenlik \\
\hline \multirow{4}{*}{$\begin{array}{l}\text { Sosyo- Kültürel } \\
\text { Alan }\end{array}$} & Sosyal Üyelik & $\begin{array}{l}\text { Toplumsal değer sistemi, topluluk duygusu, küresel } \\
\text { vatandaşlık }\end{array}$ \\
\hline & Sosyal Hassasiyet & Farklılıklara saygı, kültürler arası anlayış, \\
\hline & Sosyalleşme Yeteneği & $\begin{array}{l}\text { İletişim becerileri, kültürler arası iletişim becerileri, dil } \\
\text { akıcıllğı }\end{array}$ \\
\hline & Sosyal Görev & Grup çalışması ve görev tamamlama, liderlik \\
\hline
\end{tabular}

Tablo 2. 21.Yüzyll becerileri alt boyutları

Tablo 2'de 21. yüzyıl becerileri ile ilgili bu üç alanın alt alan ve alt alan tanımlamaları sistematik bir şekilde gösterilmektedir. Tabloda gösterilen üç ayrı alan detaylı bir şekilde açılanmaktadır.

\section{Bilișsel alan}

Günümüzdeki bilgi toplumlarında araştırma, bilgiyi oluşturma yeteneği öğrenciler için en etkin beceriler halini almıştır. Buna bağlı olarak bilgi yönetimi, bilgi yapılandırma ve gerçek yaşam problem çözme becerilerini geliştirmek günümüz öğrencileri için vazgeçilmez beceriler olmuştur. Yani, bireyin gereksinimlerine göre eleştirel değerlendirme ve doğru analiz yoluyla güvenilir ve faydalı bilgiyi seçme yeteneği eleştirel düşünme olmadan bilgiye ulaşmaktan daha önemli olabilir. Bu nedenle, bilişim ve iletişim teknolojilerinin kullanımı bilgiyi işleme ve kullanım yeteneklerini kolaylaştırır; öğrenciler ileri seviye düşünme sürecinde daha yoğun ve faydalı etkinlikler yapabilir, problemlere yönelme, eleştirel düşünme, yaratıcılık gibi alanlarda yetilerini geliştirebilir (Daud ve Husin, 2004).

\section{Duyuşsal alan}

Birçok araştırmacı bilişim ve iletişim teknolojilerinin kullanımının öğrencilerin ihtiyaçları ile orantılı olarak farklı öğrenmeler için çeşitli firsatlar sağlayabileceğini belirtmiştir (Seferoğlu ve Koçak, 2003; Tekerek, Ercan, Udum,. \& Saman, 2012). Bilgi ve iletişim teknolojileri tabanl, öğrenci merkezli eğitim alanlarında, öğrenenler öğrenme ortamlarını kendileri tasarlar. Bu noktada, her öğrenen için öz değer, öz kimlik, kendi kendini yönetme, öz sorumluluk öğrenme için kritik faktörler olarak kabul edilir.

\section{Sosyo-kültürel alan}

Bilişim ve iletişim teknolojileri ilerledikçe, dijital çağın öğrenenlerinde öncekilerden farklı olarak yeni tecrübeler ortaya çlkmaktadır. Öğrenciler ortak zaman ve ortak mekân birlikteliğinin ötesinde bilgi ve fikirlerini birbiriyle paylaşarak yeni bilişsel kazanımlar elde edeceklerdir. Bu yüzden, bilişim ve iletişim teknolojileri odaklı toplumlarda daha da başarılı olmak için iletişim yetenekleri ve farklı kültürlere saygı yetkinlikleri giderek elzem hale gelmiştir (Glimps ve Ford, 2008).

$\mathrm{Bu}$ şekildeki sosyal ve işbirlikçi öğrenmeyi kolaylaştırmak için sosyal üyelik, sosyal hassasiyet, sosyalleşme yeteneği ve sosyal ifa günümüzde bireyler için gerekli ve önemli temel becerilerdir. Ayrıca, öğrenciler açısından bu tarz sosyal ve kültürel alanlar yeni işbirliği ağları düzenlemek için elverişli firsatlar olacaktır.

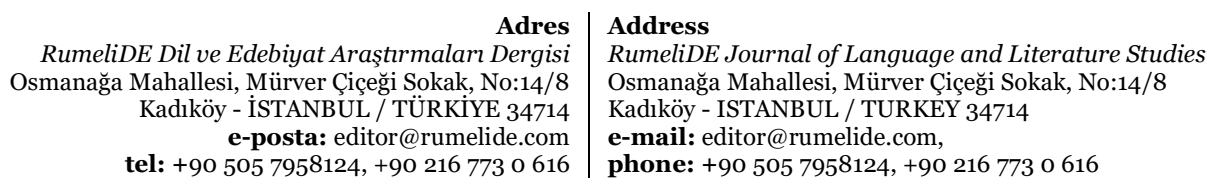




\section{Yüzyıl becerileri bağlamında öğrenci}

Teknoloji çağında bilginin doğru ve uygulanabilir kullanım alanlarında toplumsal faydaların maksimize edilmesi üzerine yapılandırılma ve yeniden inşası bir zorunluluktur. Küresel bir değişimin olduğu günümüzde diğer devletlerden geri kalmamak için yeniden şekillenen ihtiyaçlarla orantılı olarak öncelikle öğretmenlerin kendini yenileyebilmesi ve sonrasında öğrencileri de değişen şartlara göre yetiştirmeleri gerekmektedir. Öğrenenlerin bu süreçte toplumun yararına ve teknoloji tabanlı planlı eğitime tabi tutulmaları temel bir gerekliliktir.

Öğrencilerin, doğru bilgiye ulaşabilmeleri, bilgiyi yapılandırabilmeleri ve bunları kullanarak yeni bilgiler ortaya çıkarabilmeleri için belilrli becerilerle donatılmalıdır. Günümüzde 21. yüzyll öğrenme becerileri uluslararası rekabetten kopmamak adına eğitimde hayati bir işleve sahiptirler. Öğrencilere özellikle kazandırılması gerekilen temel öğrenme problem çözme, aktif öğrenme, iletişim ve işbirliği, öğrenmeyi öğrenme becerileridir. Bahsedilen öğrenme becerileri 21. yüzyll becerilerinin edinilmesi açısından önem arz etmektedir (Louis, 2012). Bilim insanları ve çeşitli uluslararası akademik kuruluşlar ve organizasyonlarca yapılan araştırmalarda 21. yüzyıl öğrenci özellikleri farklı sinıflandırmalarla karşımıza çıkmaktadır.

Uluslararası Eğitim Teknolojileri Topluluğu (ISTE) tarafindan Ulusal Eğitim Teknoloji Standartları (NET-S) adı altında yapılan bir araştırmada öğrencilerin daha kalıcı öğrenmeler gerçekleştirebilmeleri için sahip olmaları gereken standartları şu şekilde belirlemiştir: Yaratıcılık ve yenilik, iletişim ve işbirliği, eleştirel düşünme, problem çözme ve karar verme, dijital vatandaşlık ile teknolojiyi kullanabilme.

Bir başka araştırmacı olan Wagner (2008) 21. yüzyıl becerilerinin belirlenmesi konusunda çalışmalar yapmıştır ve bu becerileri yedi başlık altında formüle etmiştir. Wagner'in literatüre kazandırdı̆̆ı en önemli terimlerden birisi ise "hayatta kalma becerileri" (survival skills) dir. O, bu becerileri öğrenciler için hayati önem taşıyan beceriler olarak ifade etmiştir. Söz konusu beceriler "Hiçbir çocuk geride kalmasın (NCLB- No Child Left Behind)” ilkesiyle oluşturulmuştur. Wagner'ın özellikle ekonomik alanda faaliyet gösteren birçok üst düzey yöneticiyle yaptığı görüşmeler neticesinde sinıflandırdığı 21. yüzyıl öğreneninin sahip olması gereken beceriler; pratik zekâ ve uyumlu olma, meraklı olma ve hayal gücü, sözlü ve yazılı olarak etkili iletişim kurma, sistemler ve kişiler arası iş birliği ve liderlik, sorumluluk alma ve girişimcilik, eleştirel düşünme ve problem çözme, bilgiye erişebilme ve analiz edebilme olarak sıralamıştır.

Ekonomik İşbirliği ve Kalkınma Örgütü (OECD), 21. yüzyl öğretimine büyük önem verdiğini bu konuyla ilgili çeşitli araştırmalar yaparak ortaya koymaktadır. Bu kapsamda yapılan ve farklı eğitim sistemlerini karşılaştıran araştırmalar 21. yüzyıl öğrenen kişilerin özelliklerini listelemiştir. Bu özellikler; kültürel ve sosyal değerlerde yaşanan değişim, alternatif bilişsel özellikler, öğretme ve öğrenmeye yönelik beklentiler olarak sıralanmıştır. OECD bilgi toplumunda ortaya çıkan bilişsel özelliklerin geçmiş kuşaklardan farklı gereksinimlerinin ve niteliklerinin olduğunu vurgulamaktadır. Söz konusu alternatif bilişsel özelliklerin yeni neslin (ya da 21. yüzyll öğreneninin) öğrenme sürecinde; basılı olmayan dijital kaynaklardan bilgiye ulaşarak, görsellere, sese ve harekete öncelik verip devamlılığı olmayan ve doğrusal ilerlemeyen işlemlerle bilgi edinip, çoklu görevleri yerine getirme becerisi kazandırdığı belirtlmektedir (OECD, 2005).

$\mathrm{Bu}$ alanda çalışma yapan bir diğer kuruluş da Amerikan Okulları Kütüphaneciler Birliği (AASL: American Association of School Librarians)'dir. AASL'nin yaptı̆̆ı çalışmalar 21. yüzyll öğreneninde

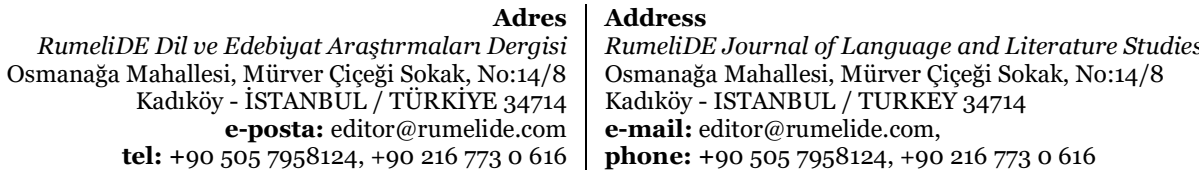


olması gereken beceriler ve kaynak kullanım alanlarını ortaya koymaktadır. Bu alanlar; kişisel ve estetik gelişme, eleştirel düşünme ve bilgi edinme, karar verebilme, araştırma, yeni durumlara bilgiyi uyarlama, demokratik katılım ve etik değerlere saygı, sonuçları belirleme ve yeni bilgi yaratma ve bilgiyi paylaşma, amaçları doğrultusunda becerilerin ve araçların kullanılması durumlarını ifade etmektedir (AASL, 2010). 21. yüzyll öğrenci becerileri içinde bulunduğu dönemin problemlerine karşı çözüm odaklı yaklaşabilen, kişinin daha kaliteli ve nitelikli bir hayat yaşaması için gerekli tüm becerileri kapsamaktadır.

\section{Yüzyıl becerileri bağlamında öğretmen}

Öğretmenin, öğrenciler ebeveynler ve toplum üzerindeki etkisi yadsınamaz bir gerçektir. Öğretmen 21. yüzyıl becerilerinin çağımız eğitim sistemine entegrasyonunda ve becerilerin öğrencilere kazandırmada kilit role sahiptir. Dolayısıyla, öğretmenlerin öğrenme sürecinde etkiledikleri öğrencileri, meslektaşları ve toplum için yaratıcı fikirler tasarlamak, uygulamak ve değerlendirmek, olumlu modeller sunmak ve profesyonel uygulamaları zenginleştirmek gibi niteliklere sahip olmaları gerekir (Günüç, Odabaşı \& Kuzu, 2013).

21. yüzyll koşul ve ihtiyaçlarına göre eğitim veren bir öğretmenin nitelikleri sadece öğrenme-öğretme sürecini yönetmekle sınırlı olmayıp, aynı zamanda yetiştirdikleri öğrencilerin toplumsal hayata adapte olmasına olumlu katkılar sağlayan, sosyalleşmelerinde önemli rol oynayan bir yol gösterici konumundadır (Gökçe, 2000). Önceki dönemlerde eğitim sürecinde öğretmeni merkeze alan, eğitimin odak noktasına öğretmeni yerleştiren bir anlayış hakimken, teknoloji devrimi ile öğrenciyi merkeze alan bir eğitim sisteminin daha etkili olduğu saptanmıştır. 21. yüzyll becerileri kapsamında konu incelendiğinde ise öğrenenlerin eğitim sürecinin merkezinde olmalarının yanı sıra eğitim amaçları belirledikleri ve bu amaçlarını gerçekleştirirken öğretenlerin rehber konumunda olduğu bir sistem önem kazanmış ve eğitim sistemi bu kapsamda şekillenmeye başlamıştır (Soland, Hamilton, \& Stecher, 2013). Yaşadığımız çağda öğrenciler, kendilerini sosyal yaşamda daha fazla yer almak ve birey olarak kabullenilmek isterler. Öğrencilerin bir ürün ortaya koyma isteği, sınır tanımaz merakı, problemler karşısındaki bakış açıları ve bunlara yönelik çözüm önerileri göz önünde bulundurularak öğretmenlerin kendilerine yol gösterici ve yönlendirici olması beklemektedirler.

Bu kapsamda, “21. yüzyllın öğretmeni nasıl olmalı?” sorusunu araştıran ABD’deki Holmes Grubu "öğrencinin performansını yükseltmek istiyorsanız kaliteli öğretmen yetiştirmek zorundasınız" görüşüne paralel olarak (Baki, Çepni, Akdeniz \& Ayas, 1996); öğrenenlerin çağımızda toplumun yeni bilgi ve beceri alanlarında uzmanlaşması, analiz ve karar alma yeteneklerine sahip olması, ve bilgiyi çekip bulmayı öğrenmesininönemli olduğunu ifade etmişlerdir (Aytaç, 2003). Öğretmenlerin 21. Yüzyıl becerileri ele alındığında yapılan çalışmalar kapsamında bütüncül bir bakış açısı ve birbirine benzer özellikler öne çıkmaktadır. Çalışmanın bu aşamasında bu alanda yapılan ve yazın alanda kabul gören bazı araştırmalara yer verilmiştir.

Milli eğitim Bakanlığı tarafından 2008 yılında "Öğretmen yeterlikleri: Öğretmenlik mesleği genel ve özel alan yeterlikleri” adıyla yapılan çalışma sonucunda öğretmen özellikleri olarak aşağıdaki kriterler belirlenmiştir. Belirtilen çalışma sonucunda bu kriterler: Kişisel ve mesleki değerler, öğrenciyi tanıma, mesleki gelişim, öğrenmeyi, değerlendirme ve izleme, öğrenme ve öğretme süreci, toplum, okul, aile ilişkileri ile içerik ve program bilgisi olarak altı ana yeterlik alanı şeklinde sunmuştur (MEB, 2008). Milli Eğitim Bakanlığı belirlenen bu yeterlilik alanlarında öğretenlerden öz değerlendirme yapma, kendini geliştirme, öğretme ve öğrenme sürecindeki faktörleri iyi kontrol edebilme, mesleki gelişimini

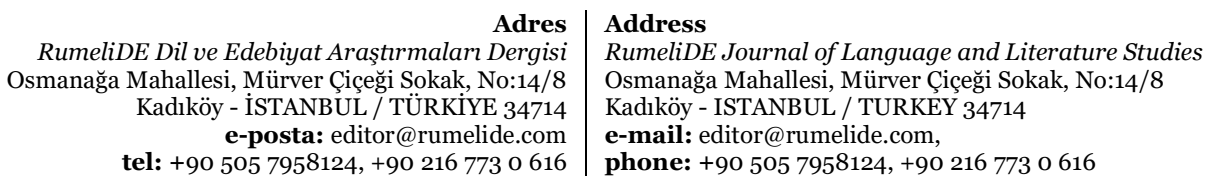


sağlayacak faaliyetlere katılma ve bunlara ek olarak öğrencilerin başarabileceğine inanma, öğrencileri anlama, öğrencilere değer verme, onların gelişimini takip ederek saptamalar yapması beklenmektedir.

Öğretmen yeterliliklerine ilişkin farklı bir araştırmayı da Lemov (2010) yapmıştır. Lemov öğretmenlerin öğretim becerilerinin geliştirilmesi için bazı teknikler belirlemiştir. Belirlediği bu teknikleri ise yedi ana başlık altında gruplandırılmıştır. Bu başlıklar; akademik anlamda yüksek beklenti, planlar yaparak akademik başarıyı artırma, dersi yapılandırarak sunma, sınıfta güçlü bir kültür oluşturma, öğrencinin derse aktif katılımını sağlama, davranışsal olarak yüksek beklentiler oluşturarak sürdürme, dürüstlüğü ve karakteri şekillendirme (Lemov, 2010; Göksün, 2016). Lemov’un geliştirdiği kuram genel olarak öğrenenlerin akademik başarıları üzerine odaklanmaktadır. Öğrencilerin akademik başarıları kapsamında akademik beklentinin yüksek tutulması durumunun öğrenciler açısından pozitif bir ivmeye sahip olduğunu aktarmaktadır. Öğrenenlerin derslere yönelik ilgi ve algılarının üst seviyeye çıkarılması konusunda özellikle modellenerek, somutlaştırılarak sunulması gerektiğini ifade etmektedir (Lemov, 2010; Göksün, 2016). Anılan tekniklerin geneli-değerlendirildiğinde 21.yüzyıl öğreten becerileri ile ilgili donanıma sahip bir öğretmenin sınıf ortamında güvenilir ve duygusal bir ortam oluşturabilen, okuyan, araştıran ve etkili biri olması beklenmektedir.

Öğretmenler kendilerini ve iş yaşamlarını risk altında hissettikleri durumlarda, pedagojik becerileri geri plana atarak sadece okul kuralları çerçevesinde hareket etmektedirler (Göksün, 2016). Öğreten yeterliliklerinin denetlenmesi ve ölçülmesinin öğretenlerin bu sürece dâhil olmak istememelerine rağmen bir gereklilik olduğu inkâr edilemez. Bu gerekliliğin farkına varan bir diğer kuramcı olan Melvin (2011) tarafından ortaya çıkartılan ölçütler oluşturulmuştur. O’na göre öğrencilerin bireysel farklılıklarının ve ayırt edici özelliklerinin dikkate alınması, mesleki gelişim düşüncesi gibi kriterleri özümseyen ve mesleki yaşantısında hayata geçiren öğreticiler iyi öğretmen olmaktadırlar. Bilgilerin aktarılması konusunda ve 21. yüzyılın gerekliliklerini yerine getirebilmek için kişilerin çeşitli öğrenme becerilerine ihtiyaç duyduğu bilinmektedir. Bu beceriler kişilerin vatandaşlık bilinçlerinin oluşması, liderlik oözelliklerinin geliştirilmesi, iletişim becerilerinin arttırılması, işbirlikçi yaklaşıma uyumlu olması gibi pek çok standardı beraberinde getirmektedir.

Öğretmenlerin belirli standartlarda uyum içinde çalışmalarına katkı sağlamak ve evrensel standartlar oluşturulabilmek adına en kapsamlı çalışma ISTE (International Society for Technology in Education) tarafından yapılmış ve ISTE standartları oluşturulmuştur. Öğrenen ve öğreten için ayrı ayrı standartlar oluşturan kurumun öğretenler için belirlediği standartlar Tablo 3’teki gibidir:

\begin{tabular}{ll}
\hline $\begin{array}{l}\text { Öğgretmen } \\
\text { Rolü }\end{array}$ & Açıklama \\
\hline Öğrenci & $\begin{array}{l}\text { Öğrencilerin fazlasıyla etkinlik planlamak ve dünyadaki akranları ile etkileşim kurarak } \\
\text { ögrenme ağları oluşturmak için teknolojiden yararlanmalarıdır. }\end{array}$ \\
\hline Lider & $\begin{array}{l}\text { Öğretmenler, öğrencilerin eğitim süreçlerine katkı sunmak ve başarılarını desteklemek için } \\
\text { lider pozisyonunda olmalıdır. }\end{array}$ \\
\hline Vatandaş & $\begin{array}{l}\text { Öğretmenler tarafindan öğrencilerin sosyal deneyimlerine katkıda bulunmak amacıyla } \\
\text { empatik davranışların geliştirileceği sanal topluluklar oluşturulmaktadır. 21.yüzyll becerileri } \\
\text { ele alındığında vatandaş olabilme ilkesi temelinde fikri ve mülkiyet haklarının yasalar } \\
\text { doğrultusunda korunması için bilinçlendirme durumları da söz konusu olmak ve kişisel } \\
\text { verilerin ve özelliklerin gizliliği ilkesi de bu anlamda ön plana çıkmaktadır. }\end{array}$ \\
\hline İşbirlikçilik & $\begin{array}{l}\text { Öğretmenler, uygulamaları geliştirmek, kaynakları ve fikirleri keşfetmek, paylaşmak, } \\
\text { problemleri çözmek için diğer öğretmenler ve öğrencilerle işbirliği yaparlar. }\end{array}$ \\
\hline
\end{tabular}




\begin{tabular}{ll}
\hline Tasarımcı & $\begin{array}{l}\text { Öğretmenler, öğrenci farklılıklarını tanıyan ve barındıran kendine özgü, öğrenci merkezli } \\
\text { etkinlikler ve ortamlar tasarlamalıdır. }\end{array}$ \\
\hline Kolaylaştırıcı & $\begin{array}{l}\text { Öğretmenler öğrencileri bilimsel, görsel ve işitsel sanat alanlarında öğrenmeye, fikir } \\
\text { geliştirmeye, problemleri çözmeye teşvik edecek ortamlar oluşturulması ve sorgulamaya dayalı } \\
\text { bir tekniğin belirlenmesinde kolaylaştırıcı rolde olmalıdır. }\end{array}$ \\
\hline Analist & $\begin{array}{l}\text { Eğitimciler, eğitimlerini yönlendirmek ve öğrencileri öğrenme hedeflerine ulaşmalarında } \\
\text { desteklemek için verileri anlar ve kullanırlar. }\end{array}$ \\
\hline
\end{tabular}

Tablo 3. ISTE tarafından belirlenen 21.yüzyıl öğretmen standartları (Voogt ve Roblin, 2012)

Tablo 3'te yer alan ve ISTE tarafından belirlenen standartlar Amerikan sosyal yapısı ve eğitim altyapısı dikkate alınarak tasarlanmıştır. Dolayısıyla bu standartların farklı ülkelere uyarlanması ancak kendi ülkelerinin toplumsal yapılarını iyi bilen ve iyi analiz edebilen eğitimciler tarafından gerçekleştirilebilecektir.

\section{Yüzyıl becerileri bağlamında öğrenme ortamları}

21. yüzyıl becerilerinin kazandırılması ve sürekliliğinin sağlanması için alışılagelmiş geleneksel öğretme yaklaşımlarından uzaklaşıp öğrenci odaklı, teknolojik olarak zenginleştirilmiş bireyselleştirilmiş öğrenme ortamlarına ihtiyaç vardır. Bu ortamlarda öğretmenler öğrencilere yol göstermeli ve bu ortamlarda öğrencinin araştırma yapması için gerekli kaynak ve dokümanlar bulunmalıdır. Gerekli şartların oluştuğu, öz düzenlemelerin yapıldığı kişiye özel sayısı her geçen gün artmaktadır (Kırtak, 2017). Türkiye'de de eğitimde istenen değişim ve ilerlemelere, becerilerin kazandırılması ve öğrencilerin etkin olarak uygulama içinde yer almasıyla ulaşılmış olacaktır (Fullan, 2007).

Öğretmenlerin, öğrenme ortamlarını öğrencinin eleştirel düşünme ve yaratıcı düşünme becerilerini kazanıp bunları geliştirecek şekilde düzenlenmesi zorunluluğunu ve çocukların çok boyutlu düşünmeleri için uygun yöntem, strateji ve teknikleri öğrenme ortamlarında kullanmaları zorunluluğu vardır (Sönmez, 1995). Uzun yıllardır kullanılagelen geleneksel sınıf ortamları yerine, bilgi çağı mutlak zorunluluk olan 21. yüzyıl becerilerini kazandırmak amacıyla etkinliklerin yapıldığı ve bunlara göre değiştirilebilir ve düzenlenebilir bir biçimde oluşturulması gereklidir (MEB, 2005). Bu ortamlar yaratıcı drama, eğitici drama, eğitsel oyun, istasyon, vb. tekniklerin uygulanmasına imkan sunan, aktif katılımın gerçekleştiği, özgürce harekete imkan sunan şekilde düzenlenmelidir. Sınıflar araştırma yapılacak mobil cihaz ve kitaplarla donatılmalı, internet erişimi sağlanmalıdır. Bu ortamlar atölyeler, zenginleştirilmiş kütüphaneler, aktif öğrenme sınıfları ve modern laboratuvarlar olarak tanımlanabilir ve sayısı her geçen gün artan bu eğitim ortamları şu şekildedir;

Aktiföğrenme sınıflarn: Öğrencilerin kendi başlarına öğrenme becerilerini kullandığı aktif öğrenme sınıflardır. Başlangıçta ABD’de Fizik alanında kullanılmaya başlamış sonrasında farklı alanlarda da hayata geçirilerek dünyaya yayılmıştır (Kırtak, 2017). Burada amaç dersin konusuna uygun etkinliklerin uygulanmasıdır. Ezberci sınıf ortamı yerine bilginin eleştirel düşünme becerileri kullanılarak özümsenmesi sağlanır. Bu sınıfların iki türü ön plana çıkmaktadır: Geleneksel aktif öğrenme ve Tam stüdyo modeli. Bunlardan ilkinde teorik ders, uygulama ve laboratuvar bölümleri ayrı şekilde planlanırken, tam stüdyo modellerinde bu üç bölüm aynı ortamda yer alır. Bu sınıflarda öğrencilerin yararlanabileceği kaynaklar, internet bilgisayarları ile deney malzemeleri bulunmaktadır (MEB, 2005; Okvuran, 2003).

Zenginleştirilmiş kütüphaneler: Bilgi ve iletişim teknolojileri yönünden çağa uygun olarak hazırlanan kütüphanelerde, eğitsel video ve dijital uygulamalar sayesinde soyut konular somutlaştırılır

\begin{tabular}{r|l} 
Adres & $\begin{array}{l}\text { Address } \\
\text { RumeliDE Dil ve Edebiyat Araştırmaları Dergisi }\end{array}$ \\
RumeliDE Journal of Language and Literature Studies \\
Osmanağa Mahallesi, Mürver Çiçeği Sokak, No:14/8 & Osmanağa Mahallesi, Mürver Çiçeği Sokak, No:14/8 \\
Kadıköy - İSTANBUL / TÜRKIYY 34714 & Kadıköy - ISTANBUL / TURKEY 34714 \\
e-posta: editor@rumelide.com & e-mail: editor@rumelide.com, \\
phone: +90 505 7958124, +90 2167730616
\end{tabular}


ve öğrenilenlerin zihinlerde kalıcılığı sağlanır. Çok yönlü ortamlar oluşturularak bireylerin sorgulama, eleştirel ve analitik düşünme becerilerinin geliştirilmesi hedeflenir. Sanal kütüphaneler oluşturulmalı ve buralarda sorumlu olarak çağın özelliklerini taşıyan ve kütüphanecilik bilgi ve becerisi bakımından donanımlı bir öğretmen bulunmalıdır (Koçak ve Çetintaş, 2015).

MEB'in Okullar Hayat Olsun Projesi kapsamında oluşturulan Z kütüphaneleri bunlara örnektir. Z kütüphaneleri beğeni çeken görsel öğelerin yanında eğitim videoları, zekâ geliştirici stratejik oyunlar, görme engellilere yönelik kitaplar ve filmler gibi herkesin kullanımına açılmış eğlendirici ve öğretici malzemeleri içermektedir. Bireylerin etkin faydalanmaları için sesli masal okuma, film izleme seansları, okuma saatleri gibi faaliyetler düzenlenmektedir. Z Kütüphaneleri ile öğrencilerin hayal dünyasını geliştirmeye yönelik destekleyici çalışmalar ile bilgi, teknoloji, medya okuryazarlı̆̆ı becerilerinin yanı sıra öğrenme ve yenilikçi becerilerin geliştirilmesi hedeflenmektedir (Ak ve Çetintaş, 2015).

Laboratuvarlar: Buralar bilimsel bilginin somutlaştırıldığı alanlardır. Fen eğitiminde öğrenilenlerin kalıcılığının sağlanmasında önemlidirler ve bilimsel bilginin ulaşılması, değerlendirilmesi, yorumlanması ve tekrar üretilmesine olanak sağlamasının yanında bireylerin bilimsel süreç becerilerinin ve yetkinliklerini kazandığı alanlardır (Demir, 2016).

Atölyeler: Bu kavram sadece fabrika ve sanayi üretim tesisleri anlamında değil yaratıcılık becerisinin olduğu her yer ve alana yönelik olarak kullanılmıştır. Atölyeler özelikle 2. Dünya Savaşı sonrası politik eğitimle ilgili olarak öğrenme ve çalışma alanlarını nitelemek için kullanılmıştır. Atölyeler görsel sanatlarda, yaratıcı drama da, tiyatro pedagojisinde kullanılmasının yanı sıra robotik tasarım gibi teknoloji uygulamalı alanlarda da gerçekleştirilmektedir (Adıgüzel, 2015). Katılımcıların belirlenen konu merkezli olarak çalışmalara aktif olarak katıldığı atölyelerde eğitsel, politik ve toplumsal sonuçların elde edildiği çalışmalar yapılmaktadır. Bu yerlerde ayrıca sorun çözmeye aktif öğrenme projeleri de geliştirilir.

\section{Sonuç, tartışma ve öneriler}

21. yüzyılın başından bugüne kadarhem küresel hem de ulusal anlamda eğitim alanında büyük bir ilerleme kaydedilmiştir. Bunun sonucunda teknoloji devrimine paralel olan gelişmeler meydana gelmiştir. Bu gelişim sürecine ayak uydurmak açısından küresel politika planlayıcılarının, insanları beceri, yetenek ve yetkinlik odaklı bir hayata hazırlamak için 21. yüzyıl becerilerini merkezileştirerek politikalar geliştirmeye çalıştıkları bilinmektedir (Hamarat, 2019). Dogmatik yerine eleştirel düşünme ve problem çözme becerilerinin arttırılması hususları incelediğimiz hemen hemen tüm çalışmalarda ortak bir beceri olarak ortaya konulmaktadır (Tuzlukova ve Prabhukanth, 2018; Toharudin, 2017). Yine iletişim becerilerinin etkin kullanılması genel özellikler arasında sayılması gereken bir diğer başlıktır. Yeni bilgiye ve değişime ulaşmanın en temel yapı taşı olan iletişim dilin temel kullanıcısı insan için vazgeçilmez bir öğedir. İteşim aracılığıyla bireyler bilgiye erişmeye çalışır (Bak, 2020). Bilgiye erişebilme ve erişilen bilginin doğru analiz edilerek kullanılması da benzer şekilde 21. yüzyıl becerilerinin en temel bileşenleri arasında kendine yer bulmuştur. Bu becerilerin ölçülmesinde ve belirlenebilmesinde beceri ve yetenek geçmişi, derecelendirme ölçekleri, performans değerlendirmeler, bilgisayar simülasyonları, durumsal yargı testleri, farklı madde türlerini içeren araçlar, portfolyolar kullanılabilmektedir.

Genel olarak 21. yüzyıl öğrenci becerileri içinde yaşadığı sosyal çevreye ayak uyduran, yaşadığı çağın sorunlarına karşı çözümler üretebilen, araştırma yapan, eleştirel düşünebilen, kendini geliştiren, yaşama farklı açılardan bakan, gelişen teknolojiyi anlayıp kullanabilen, sosyal medya okumaları ve

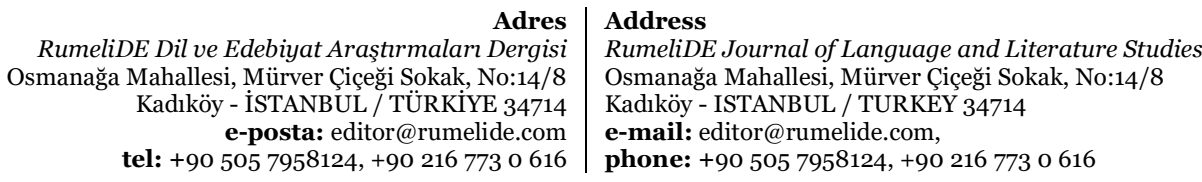


dijital okumalarını yapabilecek donanıma sahip, mesleki ve sosyal yaşamında başarıyı yakalayan kısacası bireyin daha kaliteli ve nitelikli bir yaşam sürmesi için gerekli olan tüm becerileri kapsamaktadır. Sanayi devrimi ile başlayan ve bütün dünyaya çok hızlı bir şekilde yayılan bu yeni değişim ve dönüşüm sürecinde ülkeler arasındaki ekonomik, sosyal, siyasal ve hatta askeri alanlar da dâhil olmak üzere pek çok alanda yaşanan rekabetler şekil değiştirmiş yeni bir anlayış, farklı uygulamlar hayat bulmaya başlamıştır (Dalhman, 2007). Bu durum ortaya klasik bakış açılarına sahip inanç kaynağı yerine çağın ihtiyacına cevap verebilecek, özgür, eleştirel ve inovatif düşünebilen, hayal kurabilen, alanıyla ilgili konulara pro-aktif yaklaşabilen yeni tip insan başka bir ifadeyle beşeri sermaye ihtiyacını doğurmuştur. Bu ihtiyacı karşılamanın yolunun nitelikli insan yetiştirmekten geçtiği dolayısıyla bu nitelikli insanı temelden yetiştirmek için de eğitim sisteminin beklentilere göre dönüştürülmesi gerektiği gerçeği ortadır.

Ancak bu dönüşüm öğrenci, öğretmen ve eğitim ortamı da dâhil olmak üzere tüm bileşenleri ile birlikte gerçekleşmelidir. Yeni şartlar ve ihtiyaçlara göre kendi gelişim ve dönüşümünü gerçekleştirememiş bir öğretmenin 21. yüzyll becerilerine sahip öğrenci yetiştirmesi beklenemez. Kaldı ki 21. yüzyll becerileri hayat boyu öğrenmeyi de kapsamaktadır. Benzer şekilde uygun eğitim ortamının sağlanamaması verimliliği düşüreceği gibi zaman, maddi kaynak ve işgücü kaybına neden olacak ve sonuç en yalın haliyle verimsizlik olacaktır (Chalkiadaki, 2018).

21.yüzyll becerilerine göre oluşturulmuş bir eğitim sisteminde öğrenilen bilgiler, bireylere "liderlik, girişimcilik, yenilikçilik, yaratıcılık” gibi beceriler kazandırmaktadır. Bu becerilerin 21. yüzyl ihtiyaçlarına cevap verebilecek düzeyde olması gerekmektedir. Bu nedenle neyin nasıl öğretileceğinin değerlendirmesi tüm dünyada önemli olmuş ve 21. yüzyıl becerilerinin hangileri olduğu veya olabileceği çeşitli platformlarda tartışılmış ve halen tartışılmaya devam etmektedir.

Burada sözü edilen tartışma sadece bahsedilen becerilerin neler olabileceği değil, günümüzde bir öğretmenin öğrencilerine vermesi gereken eğitimin niteliği ve metodu ile öğretenin özelliklerini de kapsamaktadır. Çünkü günümüzde öğrenciler bazen sistemden ve uygulamadan kaynaklı olarak gereğinden fazla bilgi yüklemesine maruz kalabilmektedirler. Oysa fazla bilgi yerine bilgiyi anlamlandırabilme, önemli olan veya olmayan şeyi ayırt etme ve edinilen parça halinde olan bilgilerin dünyaya ilişkin geniş bir tabloya dönüştürebilme becerisine ihtiyaç bulunmaktadır. Aynı şekilde sistem içerisinde verileri göstermeye odaklanmaktadırlar.

Öğretmenler bireyin şartlara uygun şekilde yetişmesinde başroldedirler. Öğrenciler, eğitim aldıkları öğretmenlerin bir nevi yansıması olarak hayatlarına yön verirler. Bu sebepten ötürü, rol model olma ve gerekli eğitimi verme konusunda öğrencilerini donanımlı bir biçimde yetiştirmelidir. Günün, çağın ihtiyaçlarına göre planlama yapabilmeli ve güncel içerik sunabilmelidirler (Bashir, Bajwa \& Rana, 2014; Lunenberg, Korthagen \& Swennen, 2007).

Aynı şekilde eğitim ortamları da yukarıda belirtildiği kavramlar çerçevesinde dönüştürülmeli ve bu eğitim ortamları her bireyin erişeceği yaygınlık seviyesine getirilmelidir. 21. yüzyıl becerileri eleştirel düşünme ve metabilişsel becerilerin yanı sıra gerçek hayat senaryoları ve otantik öğrenme becerilerini entegre etme ve değerlendirme yeteneğini gerektirir. Dijital okuryazarlık becerileri, teknolojinin yüksek kaliteli öğretim yöntemlerini tamamlamak için kullanıldığından emin olmak için kesinlikle gereklidir. Değerli becerilere sahip dijital teknolojiyi kullanan bireyler, 21. yüzyılda en güçlü öğrenme kaynaklarıdır (Boholano, 2017).

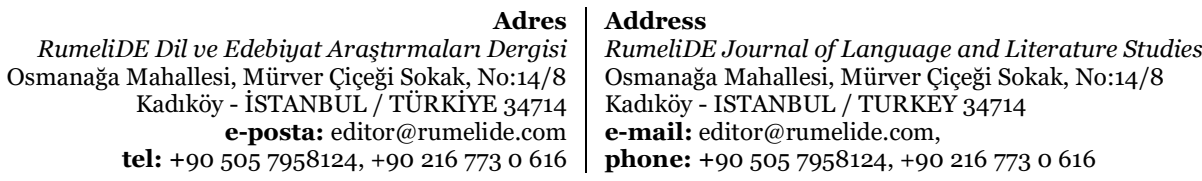


Eğitim politikaları ve uygulamaları, bireylerin; temel becerilere, özel yeteneklere ve 21. yüzyl becerilerine sahip olduğu anlayışına göre değerlendirmelidir. Bu bağlamda yapılan değerlendirmeler, 21. yüzyll becerlerini ve bu becerileri destekleyen temel yetileri derinlemesine görmeyi sağlar (Allen ve Velden, 2012). Sonuç olarak, eğitimden toplumu 21. yüzyılda yaşanan büyük değişimlere hazırlaması beklenmektedir. Bu değişimlere hazırlanırken öğretmen, öğrenci ve diğer tüm paydaşlar ile öğrenme sürecinin beceriler ile daha da zenginleştirilmesi ve olumsuz senaryolar ile karşılaşmamak adına zaman kaybetmeden tüm sistem çağın gereklerine uygun hale getirilmelidir.

\section{Kaynakça}

Adıgüzel, Ö. (2015). Eğitimde yaratıcı drama. Ankara: Pegem Akademi.

Ak, Ş. \& Çetintaş, H.B. (2015). Eğitimde zenginleştirilmiş kütüphanelerin yeri ve önemi: Ahmet Mesut Yılmaz İlkokulu zenginleştirilmiş kütüphane uygulaması, Milli Ĕ̆itim Dergisi, 44(208), 17-32.

Allen, J. \& Velden, R. (2012). Skills for the 21st century: Implications for education. Research Centre for Education and the Labour Market, Maastricht University.

American Association of School Librarians [AASL]. (2010). Sample job descriptiontitle: School librarian.

http://www.ala.org/aasl/sites/ala.org.aasl/files/content/guidelinesandstandards/learning4life/ resources/sample_job_description_L4L.pdf Erişim tarihi: 30.04.2021.

Anagün, S., Atalay, N., Kılıç, Z., \& Yaşar, S. (2016). Öğretmen adaylarına yönelik 21. yüzyıl becerileri yeterlilik algıları ölçeğinin geliştirilmesi: geçerlik ve güvenirlik çalışması. PAU Ĕgitim Fakültesi Dergisi, 40 (40), 160-175.

Aytaç, T. (2003). 21.Yüzyllın başında öğretmenin ve öğretmenin değiş̧en rolleri. Bilim ve Akln Aydınh̆̆̆nda Ĕ̆itim Dergisi. Kasım, (4), 45.

Bak, H. (2020). Türk öğrencisi bakış açısıyla rusçada cümle ve basit cümlelere dair bir değerlendirme. Atatürk Üniversitesi Sosyal Bilimler Enstitüsü Dergisi, 24 (4) , 1833-1839.

Baki, A., Çepni, S., Akdeniz, A. R. \& Ayas, A. (1996). Türkiye'de eğitim fakültelerinin yeniden yapılandırılması. YÖK/Dünya Bankası MEG Projesi.YÖK'e Sunulan Komisyon Raporu.

Bashir, S., Bajwa, M. \& Rana, S. (2014). Teacher as a role model and its impact on the life of female students. International Journal Of Research - Granthaalayah, 1 (1), 1-12.

Battelle for Kids. (2019). Networks. http://www.battelleforkids.org/networks/ edleader21-network adresinden 28.04.2021 tarihinde erişilmiştir.

Bialik, M. \& Fadel, C. (2015). Skills for the 21st Century: What Should Students Learn? Center for Curriculum Redesign Report, Boston.

Boholano, H. B. (2017). Smart Social Networking: 21st Century Teaching And Learning Skills. Research in Pedagogy, 7(1), 21-29.

Bowen, G. A.(2009). Document Analysis as a Qualitative Research Method. Qualitative Research Journal, 9(2), 27-40.

Boyacı, Ş. D. B. \& Özer, M. G. (2019). Öğrenmenin geleceği: 21. yüzyll becerileri perspektifiyle Türkçe dersi öğretim programları. Anadolu Journal of Educational Sciences International, 9(2), 708738.

Chalkiadaki, A. (2018). A systematic literature review of 21st century skills and competencies in primary education. International Journal of Instruction, 11 (3), 1-16.

Çavdar, O. \& Doymuş, K. (2016). İyi bir eğitim ortamı için yedi ilkenin işbirlikli öğrenme yöntemi ile kullanılmasının fen ve teknoloji dersinde başarıya etkisi. Atatürk Üniversitesi Sosyal Bilimler Enstitüsü Dergisi, 2O(2), 441-466.

Dalhman, C. (2007). Technology, globalization, and international competitiveness: Challenges for developing countries. Industrial Development for the 21st Century, 29-83.

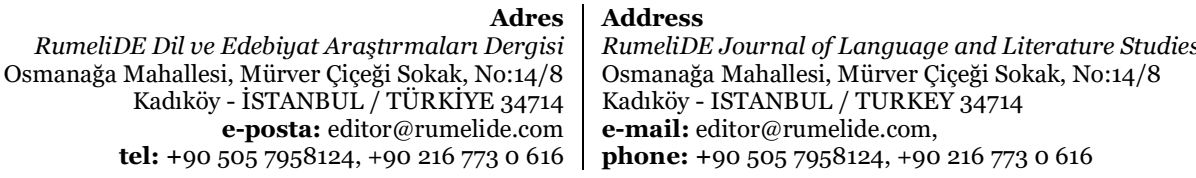


Daud, M. \& Husin, Z. (2004). Developing critical thinking skills in computer-aided extended reading classes. British Journal of Educational Technology, 35(4), 477-487.

Davenport, C. (2018). The Space Barons: Elon Musk, Jeff Bezos, and the Quest to Colonize the Cosmos, New York.

Dede, C. (2010). Comparing frameworks for 21st century skills. 21st century skills: rethinking how students learn, 20, 51-76.

Demir, E. (2016). Fen Laboratuvarlarmın fiziki şartlarını ve fen bilimleri öğretmenlerinin laboratuvar güvenliği konusundaki bilgi düzeylerinin araştırılması (Yayımlanmamış yüksek lisans tezi), Gazi Üniversitesi, Ankara.

Erylmaz, S. \& Uluyol, Ç. (2015). 21. yüzyıl becerileri ışığında FATïH projesi değerlendirmesi. Gazi Eğitim Fakültesi Dergisi, 35(2), 209-229.

Fullan, M. (2007). The New Meaning of Educational Change (4. Baskı). New York: Teachers College.

Glimps, B. J. \& Ford, T. (2008). Using internet technology tools to teach about global diversity. The Clearing House, 82(2), 92-95.

Gökçe, E. (2000). Yirmi birinci yüzyılın öğretmeni. Çağdaş Eğitim Dergisi, 270, 21-26.

Göksün, D. O. \& Kurt, A. A. (2017). Öğretmen adaylarının 21. yüzyll. öğrenen becerileri kullanımları ve 21. yüzyıl. öğreten becerileri kullanımları arasındaki ilişki. Ĕ̆itim ve Bilim, 42(190), 107-130.

Göksün, D.O. (2016). Öğretmen adaylarmm 21. yy. öğrenen becerileri ve 21. yy. öğreten becerileri arasındaki ilişki. (Yayımlanmamış Doktora Tezi). Anadolu Üniversitesi, Eskişehir.

Günüç, S., Odabaşı, H.F. \& Kuzu, A. (2013). 21. yüzyll öğrenci özelliklerinin öğretmen adayları tarafindan tanımlanması, Ĕ̆itimde Kuram ve Uygulama, 9(4), 436-455.

Hamarat, E. (2019). 21. yüzyıl becerileri odağında Türkiye'nin eğitim politikaları (In focus on 21st century skills Turkiye's education policy). SETA Analiz, No. 272.

Harari, Y. N. (2018). 21.yüzyıl için 21 ders (S. Siral, Çev.). İstanbul: Kolektif Kitap.

Hasırcı, S. (2018). Anadili öğretiminde çok uyaranlı eğitim ortamı ve bu ortamın bileşenlerinin önemi. Turkish Studies, 13(19), 895-922.

ISTE (2016). About ISTE.

http://www.iste.org/docs/StandardResources/istestandards_students2016_o nesheet_final.pdf?sfvrsn=0.23432948779836327 adresinden 28.04.2021 tarihinde erişilmiştir.

Kırtak, V.N. (2017). Tam stüdyo modelinin fen bilgisi öğretmen adaylarmın kavramsal anlamaları ile sosyal duygusal öğrenme, sorgulama ve bilimsel süreç becerilerine etkisi: akışkanlar mekaniğ $i$ örneği, (Yayımlanmamış doktora tezi), Balıkesir Üniversitesi, Balıkesir.

Koçak, M. \& Çetintaş, H.B. (2015). Okul kütüphanelerinde iletişim algısı, özel okul kütüphaneleri örneği, Milli Ĕgitim Dergisi, 44 (208), 158-172.

Lai, E. R. \& Viering, M. (2012). Assessing 21st century skills: Integrating research findings. Vancouver, B.C.: National Council on Measurement in Education.

Lee, J. (2020). These 23 companies are working on coronavirus treatments or vaccines - here's where things stand. Market watch https://www.marketwatch.com/story/these-nine-companies-areworking-on-coronavirus-treatments-or-vaccines-heres-where-things-stand-2020-03-06 adresinden 28.04.2021 tarihinde erişilmiştir.

Lemov, D. (2010). Teach like a champion 49 techniques that put students on the path to college. https://juliusbucar.files.wordpress.com/2017/04/teach-like-a-champion-49-techniques-thatput-students-on-the-path-to-college.pdf, adresinden 30.04.2021 tarihinde edinilmiştir.

Livingstone, S. \& Bober, M. (2005). UK children go online: Final report of key Project findings. London: LSE Research Online. http://eprints.lse.ac.uk/399/1/UKCGO_Final_report.pdf adresinden 30.04.2021 tarihinde indirilmiştir.

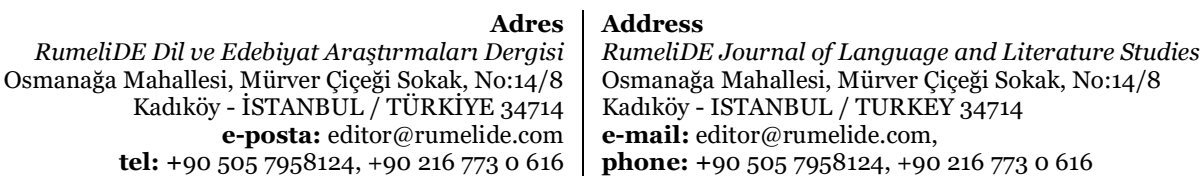


Louis, R. C. (2012). A case study exploring technology integration and incorporation of 21st century skilss in elementary classrooms. College of Professional Studies Northeastern University, Boston, Massachusetts.

Lunenberg, M., Korthagen, F. \& Swennen, A. (2007). The teacher educator as a role model. Teaching and Teacher Education 23, 586-601.

MEB, (2005). Millî Eğitim Bakanlı̆̆ talim ve terbiye kurulu başkanlığı ilköğretim fen ve teknoloji öğretim programı. Milli Eğitim Bakanlığı, Ankara.

MEB, (2008). Öğretmen Yeterlikleri: Öğretmenlik Mesleği Genel Ve Özel Alan Yeterlikleri 2. Parça. Ankara: Devlet Kitapları.

Melvin, L. (2011). How to keep good teachers and principals: practical solutions to today's classroom problems. R\&L Education.

NRC. (2011). Assessing 21st century skills: Summary of a workshop. DC: The National Academies.

OECD (2005). The future of education and skills: Education 2030. https://www.oecd.org/education/2030/E2030\%20Position\%20Paper\%20 adresinden 28.04.2021 tarihinde erişilmiştir.

Okvuran, A. (2003). Drama öğretmenlerinin yeterlilikleri. Ankara Üniversitesi Eğitim Bilimleri Fakültesi Dergisi.36(1-2), 82-87.

Organisation For Economic Co-Operation And Developmentoecd (OECD), (2006). Assessing Scientific, Reading and Mathematical Literacy: A Framework for PISA 2006, OECD Paris. http://www.oecd.org/education/school/assessingscientificreadingandmathematicalliteracyafra meworkforpisa2006.htm adresinden 29/04/2021 tarihinde edinilmiştir.

Organization for Economic Cooperation and Development (OECD). (2003). The definition and selection of key competencies. http://www.oecd.org/dataoecd/47/61/350703677.pdf adresinden 28.04.2021 tarihinde erişilmiştir.

Özkan, M., Al, A. \& Yavuz, S. (2018). Uluslararası politik ekonomi açısından dördüncü sanayi-endüstri devrimi’nin etkileri ve Türkiye. Marmara Üniversitesi Siyasal Bilimler Dergisi, 1 (1), 1-30.

Seferoğlu, S. \& Koçak, Y. (2003). Eğitim fakültelerindeki öğretim elemanlarının bilgisayar kullanımı ve özyeterlik algıları, Bilişim Teknolojileri Iş̧ğında Ĕ̆itim Konferansı ve Sergisi (BTIE), 21-23 Mayıs 2003, ODTÜ Kültür ve Kongre Merkezi, Ankara.

Soland, J., Hamilton, L. S., \& Stecher, B. M. (2013). Measuring 21st century competencies: Guidance for educators. The Asian Society. CA: RAND Corporation.

Sönmez, V. (1995). Yaratıcı okul, öğretmen, öğrenci, yaratıcılk ve eğitim. Ankara: Şafak Matbaacılık.

Tekerek, M., Ercan, O., Udum, M.S. \& Saman, K. (2012). Bilişim teknolojileri öğretmen adaylarının bilgisayar öz-yeterlikleri. Turkish Journal of Education, 1 (2), 1-12.

Toharudin, U. (2017). Critical thinking and problem solving skills: how these skills are needed in educational psychology? International Journal of Science and Research, 6 (3), 2004-2007.

Trilling, B. \& Fadel, C. (2009). 21st Century skills: learning for life in our times. San Francisco: JosseyBass.

Tuzlukova, V. \& Prabhukanth, K. U. (2018). Critical thinking and problem solving skills: engliih for science foundation program students' perspectives. Collection Of Papers Of The Faculty Of Philosophy, Research Paper, 48 (3), 37-60.

Türk, E. (1999). Milli Eğitim Bakanh̆̆̆’nda yapısal değişmeler ve Türk eğitim sistemi. Ankara: Nobel.

Uçak, S. \& Erdem, H.H. (2020). Eğitimde yeni bir yön arayışı bağlamında "21. yüzyll becerileri ve eğitim felsefesi”. Uşak Üniversitesi Ĕ̆itim Araştırmaları Dergisi, 6 (1), 76-93.

Voogt, J., \& Roblin, N. P. (2012). A comparative analysis of international frameworks for 21st century competences: Implications for national curriculum policies. Journal of curriculum studies, 44(3), 299-321.

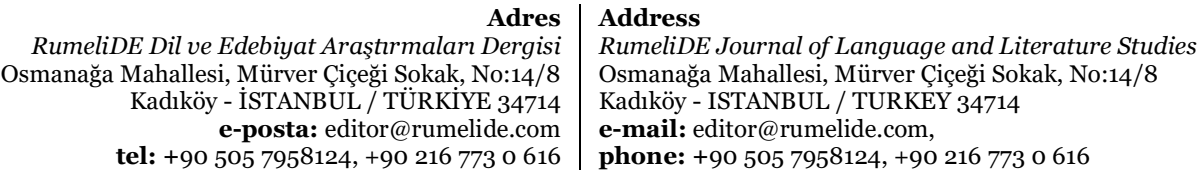


Wagner, T. (2008). Even Our "Best" schools are failing to prepare students for 21st-century careers and citizenship. Educational Leadership, 66(2), 20-25.

Yalçın, S. (2018). 21. Yüzyıl becerileri ve bu becerilerin ölçülmesinde kullanılan araçlar ve yaklaşımlar. Ankara Üniversitesi Ĕ̆itim Bilimleri Fakültesi Dergisi, 51 (1), 183-201.

Ylldırım, A. \& Şimşek, H. (2008). Sosyal bilimlerde nitel araştırma yöntemleri. Ankara: Seçkin.

Address

RumeliDE Journal of Language and Literature Studies

Osmanağa Mahallesi, Mürver Çiçeği Sokak, No:14/8

Kadıköy - ISTANBUL / TURKEY 34714

e-mail: editor@rumelide.com,

phone: +90 505 7958124, +90 2167730616 